\title{
パネルディスカッション
}

\section{4. 医療経済と医療政策}

田中 滋

Key words：市場競争，セイフティネット，尊厳と自立の支援，社会的連帯

\section{1. 医療経済をめぐる現状認識}

日本の医療費対GDP比はOECD加盟国中の低 位グループに属する．その值はアメリカの約 1 /2,ドイッの $2 / 3$ にすぎず，少なくともマクロ 経済レベルではかなり少ない医療支出でシステ ムを維持してきた。帆に「医療システムの 高度化と質の向上を推進すべく，ょり多くの資 源投入が欠かせない」との主張は当然である. また，医療分野への支出がマクロ経済成長に貢 献することも複数の産業連関分析により証明さ れている.

しかしそうした前向きの政策の検討以前に, 相対的に少ない「医療費対GDP比率」にもか かわらず, 勤労世代の医療費負担感が大きい原 因は，高齢者医療（退職者医療制度と老人保健 制度)に対する拠出金の重さゆえに他ならない。

具体的には, 現在の高齢者医療に対する拠出 制には三つの久点を指摘できる。第 1 の久点は 主体性の欠如である. 老人保健制度は独立した 保険制度ではない，老人保健制度という美しい 名前が付いているが，これは一種の財政調整の 仕組みにすぎない，誰かが保険者として積極的 に管理している体制とは異なる，本質が財政調 整の仕組みなので, 老人保健制度が給付する医

たなか しげる：霖研義熟大学経営大学院
療の内容について, 誰が保険者としての最終責 任をとるのかはっきりしない。何らかのかたち で勤労世代が高齢者を金錢的に支援しなければ ならないにしても，主体性を伴わない方式によ るこれ以上の負担は，負担する側が納得してく れないところまで来てしまった.

第 2 の久点は会計の最終確定が遅い点であ る. 1999年の政管健保の赤字は, やっと1997年 前の拠出金の金額が定まったため2000年秋に確 定できた．企業経営で言えば，世の中に対する 迅速な説明責任（アカウンタビリティ）を果た していないと非難されるだろう。3 年前の概算 払いに関わる会計整理がやっと終わって，去年 の財政を最近発表できるという遅さである。そ もそも株式会社では, 経営陣は予算に対する責 任よりも，決算に対する責任が大きい，予算で どんなに魅力的な美しい経営政策を語っても， 業績が悪ければ社長は批判され，株価は下がる。 ところが，公務員にとっては予算の方が大切で あり，国会で審議されるが，議決事項ではない。 2 年後に国会に報告されるにとどまる。また決 算が狂っても，もし予算策定時の担当者が異動 していれば，遡って責任を追求されるわけでは ない.

第 3 の欠点は，国全体で子供の数が減ってい る中で，現在の拠出金は子供がたくさんいる保 険者は拠出金を多く納める方式になっている点 があげられる，組合健保でも，共済でも，子供 
をたくさん産む家族が多いと，拠出金が増える 計算式の影響を受けてしまう. 少子化社会にお いてはとんでもないペナルティではなかろう か. 子供をつくらないほうが経済的に得になる ようでは，長期的には日本社会の墓穴を掘るこ とになりかねない.

\section{21世紀の経済・社会}

日本経済の生産面においいては好むと好まざる とにかかわらず，これまで政府の規制や支出に よって守られてきた産業も，国際的に開かれた 競争に直面していく．その代表例である金融業 ・農業・通信業などのみならず，事実上は棲み 分け状態が珍しくなかった医療機関も今までよ り厳しい競争環境への変化を避ける賴沢は許さ れない。ゆえに各組織は, 自らの経営理念を時 代に合わせて再確認するとともに，資源（人 • 資金・技術・建物設備等) 投入可能量が定める 制約をふまえ，改めて事業コンセプトを明確に 構築する必要がある，さらに，事業コンセプト によって選んだマーケットにおける自己の相対 的ポジションを定め, そのポジションで競争に 耐えるための最新の事業管理技術を確実に把握 しなくてはならない.

20世紀とは次元の違う競争をもたらすこのよ うな変化は, 経済が基本的に冷徹な市場ルール の下におかれる国際社会の状況を反映してい る. そして市場競争が強化される結果, 「競合 相手に敗れた供給者の市場からの脱落」，およ び「脱落回避のための努力と工夫」を通じ，少 なくとも財貨サービスの生産についてはより効 率的な資源配分に近づいていくだろう，競争で 負ける理由には, 競合する商品・サービスに劣 る技術水準や品質, 当該商品・サービスの魅力 の陳腐化, 相対的な高コスト・高価格, 財務管 理や人事管理の失敗，環境問題や政治・行政之 の関係に対する古い体質がもたらす悪評等々， 実にさまざまなケースが考えられる。一方，勝
者が享受する高い利益率(これについては後述) と一層の資金調達の可能性が，市場競争メカニ ズムの下での裹賞の本質である.

さらに，供給者間競争は原理の一面にとどま る。それと同時に，「競争に敗れる消費者の市 場からの脱落」もまた, 市場経済における冷酷 な論理であることを忘れてはならない。ではど ういう理由で消費者は市場競争から脱落するの だろうか。こちらの答えは簡単で，「買うだけ の資金力がない」につきると言ってよい.どれ だけ病気の人が治療を望んでも，裸の市場経済 の下では、ニーズだけではサービスの利用に直 接結びつかない，家計の購買能力，もしくはそ の社会の経済力が実際の消費量を決めてしまう からである。これは好ましい帰結とは思えない。

\section{3. 社会保障制度の位置づけ}

続いて，社会保障制度の位置づけを考えてみ たい(図)。この図を使うと，日本の社会保障 制度全体をどの方向に持っていくべきか，それ に対し今誰がどういう案を主張しているかが分 かりやすく整理できる。

縦軸は政策的な意思決定にかかわる公私の権 限を表している，上に行くほど民間主体の自立 を尊ぶ考え方，下に行くほど政府によるコント ロールを重視する考え方を示している，民間主 体とは，個人あるいは家計，企業，病院，大学， 社会福祉法人，NPOなどの組織を指す．民間 や基礎自治体の自立と自己責任を重く見る立場 は，縦軸に沿って上の方に位置する，反对に， 縦軸の下の方は「弱者保護と依存」を表す。

一方，横軸は富の再分配を示す. 財貨・サー ビスの生産によって付加価值が発生した際，そ れを生産に携わった人と資本だけが受け取るの ではなく,生産過程には参加しなかったものの， やはり富を必要とする人やセクタに一部を配り 直す場合が珍しくない。この過程を経済学では 再分配と呼ぶ. そして, 近代の人権を尊ぶ国家 
自立：(1)個人，(2)集合体（家計・企業・NPO等），(3)住民主権の自治体

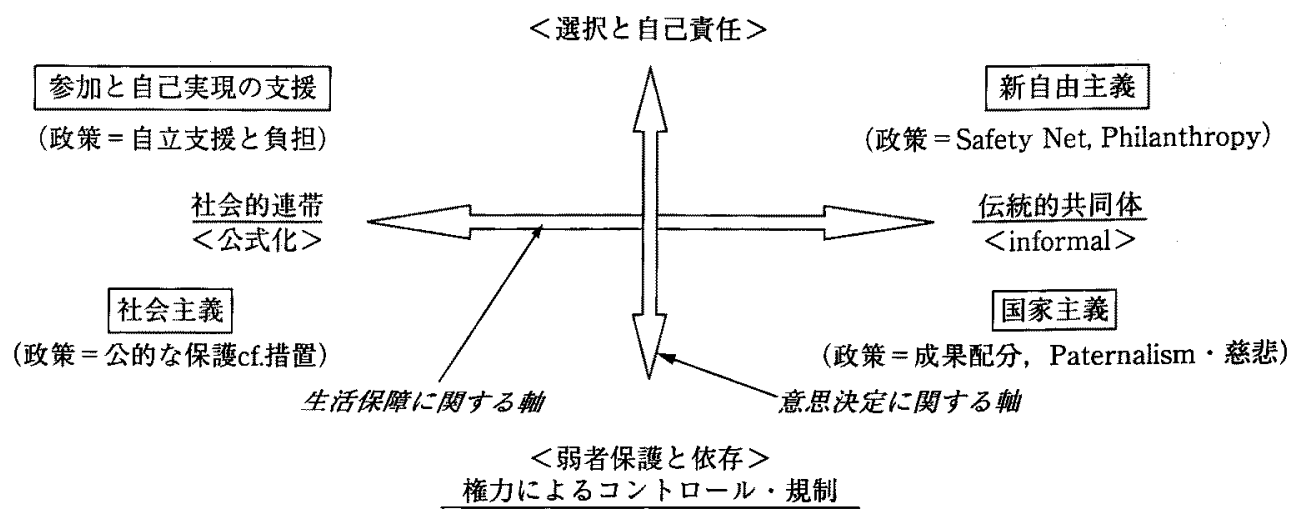

図、社会保障政策の位置つけ

では再分配が必ず行われている，再分配の方法 として，左に行くほど公的な制度を通じた社会 連帯の重視を表すのに対し，右に行くほど個人 や伝統的共同体の役割が重視される. 伝統的共 同体とは，家族やローカル・コミュニティなど を指す．この 2 つの軸を用いると，4つの思想 を明確に区分できる。新自由主義，国家主義， 社会主義,そして日本ではこれまで弱かった「尊 厳と自立の支援」の考え方である。

右上の新自由主義は, 個人の自己責任を強調 する、したがって, 社会保障についても, 自己 責任では生きられない人に対象を限定するセイ フティネット，すなわち救貧の概念から出発す る.そこでは，「負しいこと」が受給の資格条 件になる，古い社会福祉制度はまさにそうだっ た（幸い今の日本では，社会福祉構造改革によ り救賓の色彩が薄れてきたが).

セイフティネットによる保障を受けるために は，「困窮の度合い」を自分で証明しなければ ならない. 生活保護が典型である。生活保護の 受給は，憲法に基づく権利とはいえ，自分の経 済状態を裸にしなければならない。所得だけで はなく，家族状況や資産もさらけ出さなければ 「福祉のお世話」にはなれない。残念ながら， その過程では人間の尊厳を守れないような事件 が起き，裁判となったケースが見られた事情は
ご存知のとおりである.「クーラーがあると対 象からはずす」，もっと前には「テレビがあっ てはいけない」という時代があった。こうした 制度が不要だと非難したいわけではない，負し い人々が存在する以上，欠かせない制度とはい え，セイフティネットによる救貧の概念を社会 保障全体に当てはめてはいけないと論じている のである.

では，なぜこういうセイフティネット概念に 立脚しながらイギリスやアメリカの社会が機能 しうるのだろうか。、それは, 両国, 取り分け合 采国にフィランソロピー，博爱の精神による寄 附が根づいているからである。アメリカでの民 間寄附金額は年間 20 兆円以上に達する，米国に は地域コミュニティ単位での助け合いの思想が 強いため，国家による保障がなくてもストレー トな資本主義を活用しやすいが，プライベート な寄附金が市場経済を補完するほどには奖励さ れない社会では，市場経済論者の主張するよう に何でも裸の市場競争を当てはめると, 多くの 生活者が社会に参加できなくなってしまう. 病 気がちの子供をもった家庭, 要介護のお年より を抱えた家庭が，支援なく市場経済に参加でき るとは思えない。

救負概念に基づく社会保障は，「筫しい人を 放置しておくと過激化しかねないので，最低限 
の保障を国家が主導する」19世紀の社会政策が はじまりであった. 百歩譲って日本でもセイフ ティネット型保障まで縮小させたいなら，まず 寄附金の所得控除，贈与税の免除対象を広げな くてはならない.

\section{4. 国家主義と社会主義：弱者保護思想}

右下のステイティズム＝国家主義の思想で は，家族を含む伝統的共同体の役割が強調され てきた。この思想によれば，国家とは，近代的 な機能を果たす主体より，「長」を筧大な父親 になぞらえた最も大きな擬似家族と捉える，国 家主義の立場から見ると, 社会保障は弱者を保 護する慈悲の心の現れである．自ら社会的な高 みに立って弱者を守る, 英語で表せばパターナ リズムの世界になる。パターナリズムでは，パ ターナリスティックな慈悲心の対象と定めた弱 者を守ろうとする.その典型が一昨年秋の介護 保険 1 号保険料の徴収延期論に他ならない.「お 年寄りがかわいそうだから取ってはいかん」と の見解が示されたように，まさに「自分が守る と決めた人は守る」，つまりは「自分の方が強 い」という立場に立った，連帯とは違う思想だ と言える.

一方, 左下の社会主義の哲学では, 平等なサー ビスの受益が目標になる.平等を図るためには, 公的セクタが非公共財についても自ら生産を担 うべきだとの発想が強い。しかし，現実には民 間主体の活用に比べると明らかに資源配分の効 率が悪くなる，社協のへルパーと民間企業のへ ルパーの間に見られる貨金 1 円あたりの生産性 の違いは著しい，また，かつての社会主義国の 現実を思い出せば分かるように, 平等の建前の もと，しばしば政治権力による不明朗な配分が なされてきた。市場経済と違って，権力に近け れば近いだけ分配を受けやすかった事実は否定 できない。現実の人間行動ゆえに，社会主義が 理想とはほど遠い機能しか果たさなかった歴史
は，私たちが20世紀に学んだとおりである。

\section{5. 参加と自己実現 $=$ 自立支援}

最後に，左上の「尊綮と自立を支援する思想」 では，民間主体の自立と同時に，公的な制度を 通ずる公正な連帯を大切にする。したがって， 例え100歳であっても, 経済力に応じて社会連 帯に貢献すべきだと考える．「経済力に応じて」 である以上，所得や資産が少なければ貢献義務 は隇免される一方，100歳でも所得がもし1,000 万円あれば，勤労世代の1,000万円稼得者と同 じように，公正に社会に貢献していただく. 単 に100歳であるがゆえに貢献を免除する仕組み は正しくない，その代わり医療や介護が必要に なったら, サービスを‥適切な自己負担は別と して‥使いやすいように支払いの支援を行う。 本当に貧しければ自己負担も免除しても良い。

他方，公共財を除く供給面に関して言えば, 民間主体はもとより，公的な提供者であっても， できる限り自立した事業体になり，政府の一般 会計などで赤字を補てんするのではなく，個々 の主体ができる限り顧客志向のために品質とコ ストをめぐる努力をすべきだと考える。その点， 供給面については新自由主義とあまり変わらな い主張と言ってよい. 新自由主義と大きく異な る点は, 一定分野, 例之ば医療, 介護, 保育, 教育などの利用者のための連帯の仕組みをしっ かりつくっておかなければ, 社会が健全に機能 しないとの認識の強弱である. 左上の思想では, 社会保障制度の本質を, 救筫のためのセイフ ティネットではなく, 住民が安心感を持って生 きるための防筫，すなわち筫しくなることを防 ぐ機能と捉える。この違いが大変大きい.

病気や要介護状態になること自体は，どんな に保険制度が発達しても完全には防げない。だ れもがどこかでインフルエンザに䍜患するかも しれない. 社会保険制度があろうとなかろうと 確率的にインフルエンザ患者は発生する。年を 
とればどこか悪くなるし，中には要介護になる 方もおられる。しかし，誰かが病気や要介護に なったとき，それゅえに家計が筫しくなる心配 をなくす，これが連帯の思想に基づく社会保障 制度の本質である．貿しくなったらそこではじ めて助けるのではなく，病気の治療ゆえに，あ るいは要介護者の発生によって家計が筫しくな ることがないよう,ニーズに応じて給付を行う． この社会的連帯の制度をしっかり築くべきだと 主張する点が新自由主義との違いである，そも そも要介護状態のお年寄りがいたり, 病気に なったりという事態そのものが不幸なのに，さ らに加えて治療費や介護費で貧しくなるような 二重の不幸を負わせる社会では, 国際経済競争 に立ち向かう基礎となる安心感が確保できない からである。
人は財貨サービスの「生産者」としてだけ生 きているわけではなく，「生活者」でもある. 生活者としてのわれわれにとっては，だれかの 配偶者であり, 親であり, 子どもであり, 友人 であり, 恋人であり, 教師であり, 生徒である という関係性が大きな意味を持つ。そして高秢 社会になればなるほど，そうした側面の重みが 增していくと考えられる. 生活者が持つ人間関 係には市場原理はなじまない。市場原理で親を 決めたり，恋人を選んだりする事態はありえな い. 相手を好きになったら，理由なくそれ自体 が結論であり,「リスクを勘案しつつ収益がもっ とも高いプランを選んで投資する行動」とは まったく原理が異なっている.「参加と自己寒 現」の思想は, 経済の原理とは違う, 市場を超 えた高い価値である。 